\title{
The thermal seasons variability in Poland, 1951-2010
}

\author{
Bartosz Czernecki $^{1}$ (D) Mirosław Miętus $^{2}$
}

Received: 15 April 2015 / Accepted: 24 September 2015 / Published online: 5 October 2015

(C) The Author(s) 2015. This article is published with open access at Springerlink.com

\begin{abstract}
The aim of this study is to detect variability and changes in the occurrence of the thermal seasons in Poland during the period from 1951 to 2010 . A monthly temperature dataset using average area values allowed the researchers to set proper occurrence dates for the thermal seasons' beginnings and length according to the following criteria: winter $\left(t<0{ }^{\circ} \mathrm{C}\right)$, early spring $\left(0-5^{\circ} \mathrm{C}\right)$, spring $(5-$ $\left.15^{\circ} \mathrm{C}\right)$, summer $\left(t>15^{\circ} \mathrm{C}\right)$, autumn $\left(5-15^{\circ} \mathrm{C}\right)$ and early winter $\left(0-5{ }^{\circ} \mathrm{C}\right)$. Statistically significant long-term trends have been detected for the occurrence dates of the thermal seasons' beginnings and season length. Seasonal variability accelerated significantly since the end of the twentieth century. The trend of limiting wintertime in Poland is 0.64 days per year, while summer and early spring seasons are longer by approximately 0.30 and 0.25 days per year, respectively. All seasons since thermal early spring until thermal summer tend to occur earlier, while the following seasons have the opposite trend. As a result, the number of years without thermal winter has substantially increased in the past 20 years. Simultaneously, thermal summer became the longest season in $85 \%$ of years after 1990 in comparison to less than $50 \%$ in the period from 1951 to 1970 . Also, the change in the annual course of monthly mean temperature results in the fact that thermal spring is becoming longer than thermal autumn.
\end{abstract}

Bartosz Czernecki

nwp@amu.edu.pl

1 Department of Climatology, Adam Mickiewicz University in Poznań, Dzięgielowa 27, 61680 Poznań, Poland

2 Department of Meteorology and Climatology, University of Gdańsk, Bażyńskiego 8, 80-952 Gdańsk, Poland

\section{Introduction}

The impact of global warming on the seasonal structure of the climate is becoming a more and more common field of climatological studies, mainly due to its effects on natural and social systems (Pielke et al. 2002). According to the BACC report (2008), the estimated linear trend of mean temperature increase in the years $1871-2004$ is about $0.07{ }^{\circ} \mathrm{C}$ per decade in the Baltic Sea Basin countries to the south of $60^{\circ} \mathrm{N}$, which is almost equal in comparison to the values reported in the Fourth Assessment Report of the IPCC (2007) that refer to observed global warming in the twentieth century $\left(0.6 \pm 0.2^{\circ} \mathrm{C}\right)$.

On the other hand, the signal of climate change strongly varies seasonally, with the highest increase of air temperature observed especially in wintertime (Degirmendžić et al. 2004). It results in decreasing tendency of annual amplitude (Wibig and Głowicki 2002), which makes the climate of Poland more maritime, accordingly with the growing intensity of the NAO index. Concurrently, changes of air temperature reflect to an observed seasonal pattern, often perceived by wide range of people equivalently as a climate change evidence (Rebetez 1996). In a temperate climate zone, increases in mean air temperature usually induce an earlier onset and a lengthening of the growing seasons (Carter 1998; Menzel 2003; Kożuchowski and Degirmendžić 2005; Song et al. 2009; Irannezhad and Kløve 2015), described as any period with a daily mean temperature above $5{ }^{\circ} \mathrm{C}$. An earlier onset is also typical for spring and summer, while autumn and winter begin later (Ruosteenoja et al. 2010).

So far, research considering climate change in terms of seasonal variability concentrated on present states and the future of agriculture potential based on phenological observations (Menzel and Fabian 1999), while possibility of using thermal season appearance as a climate change indicator was 
diminished or used only on a regional scale. As presented in some papers (Rapp and Schoenwiese 1994; Jaagus et al. 2003; Kożuchowski and Degirmendžić 2005; Ruosteenoja et al. 2010), the sensitivity of the thermal seasons' occurrence may vary depending on the region and may have different impact on the environment, its adaptive capabilities, including further agricultural and food production problems (Kramer et al. 2000; Lobel and Field 2007). This fact causes an increase of interest in thermal seasons' variability as an additional index of climate changes, which follow the direct perception of humans (Rebetez 1996). Knowledge about the temporal variability of the thermal seasons may be also essential in detecting tendencies of climate change in particular sub-periods of year, which is valuable information for the governmental purposes of future planning.

In consideration of the above premises, the aim of this study is to present the characteristics and temporal variability of the thermal seasons in Poland, with a focus on extreme events of seasons' occurrence. The authors also determined the tendencies observed in the period of analysis and discover whether they follow the tendencies presented in climate change reports.

\section{Methods, dataset and area of research}

Defining thermal seasons was a subject of many purely theoretical debates concerning methods of determining and establishing the number of thermal seasons. Many papers considered eight thermal seasons in relation to phenological conditions (Piotrowicz 2010), four seasons while referring to astronomical or meteorological criteria (Pielke et al., 1987; Rapp and Schoenwiese 1994; Tveito et al. 2000; Ruosteenoja et al. 2010), and six seasons according to original attempts at disambiguation (Jaagus et al. 2003; Czernecki and Miętus 2010).

The classification presented below is one of the most common and widely used in Central Europe, and it follows Romer's methodology (1949). It is based on the monthly mean values of air temperature and threshold values for every part of the year, as shown in Table 1.

In order to establish the onset date precisely, formulas for the rising (1) and falling (2) phase of the mean temperature were employed:

$x=\frac{t_{p}-t_{1}}{t_{2}-t_{1}} n$

$x=\frac{t_{1}-t_{p}}{t_{1}-t_{2}} n$

where:

$t_{1}$ is the monthly mean temperature in the month preceding the crossing of the threshold value, $t_{2}$ is the monthly mean temperature in the following month, $t_{\mathrm{p}}$ is the threshold value, $n$ is the
Table 1 Threshold values adopted for calculating thermal seasons' onset from monthly means according to Romer (1949)

\begin{tabular}{lcc}
\hline Season & $\mathrm{t}_{\min }\left[{ }^{\circ} \mathrm{C}\right]$ & $\mathrm{t}_{\max }\left[{ }^{\circ} \mathrm{C}\right]$ \\
\hline Winter & & 0 \\
Early spring & 0 & 5 \\
Spring & 5 & 15 \\
Summer & 15 & \\
Autumn & 5 & 15 \\
Early winter & 0 & 5 \\
\hline
\end{tabular}

number of days in the previous month, and $x$ is the number of days to be added to the 15th day of the previous month.

The use of mean daily air temperatures, even if usually more accurate for determining onset dates, may be misleading in many cases due to rapid fluctuations in air temperature during some periods in the first half of the year (Czernecki and Mietus 2010). It means that a threshold value can be crossed even a few times in a relatively short period of time, what may result (in utter cases) in differences up to 2 weeks in determined thermal season's onset date depending on applying monthly or daily dataset (Czernecki and Miętus 2010). Keeping that in mind, the authors decided to choose the less subjective approach which is based on monthly mean air temperatures and respective formulas (Eq. 1, Eq. 2) for calculating onset dates. In particular years without thermal winter (monthly mean temperature always above $0{ }^{\circ} \mathrm{C}$ ), termination of early winter was established by dividing length of whole period with temperature below $5{ }^{\circ} \mathrm{C}$ into two equal subperiods. Since the beginning of thermal winter may occur either before or after the turn of the year, the years given in the manuscript reflect to the second alternative (i.e. in case the thermal winter starts in November or December, the year indicated in the manuscript is as if this season starts in January or February the following year).

The analysis is based on data derived from 45 stations maintained by the Institute of Meteorology and Water Management-National Research Institute (IMGW-PIB). All stations include the complete and quality-controlled dataset since January of 1951 to March of 2011 and are fairly evenly distributed over the territory of Poland (Fig. 1). Selected stations represent the regional mean elevation quite well with the average elevation for all stations only $14 \mathrm{~m}$ lower than that for the whole area of country (stations above $1000 \mathrm{~m}$ amsl were excluded). The entire area of Poland was additionally divided into seven physio-geographical regions from north to south according to traditional, geographical division of country (Kondracki 2002; Fig. 1). The regions of Lakelands, Lowlands, and entire area of Poland were additionally splitted onto eastern and western subregions to show the typical for Polish climate east-west gradients (Ustrnul and Czekierda 2005, Fig. 2).

The final value for an area's monthly mean $\left(\mathrm{T}_{\mathrm{avg}}\right)$ was calculated according to the method applied by the Polish Climate Monitoring Bulletins (Biernacik et al. 
Fig. 1 Locations of the analysed stations for the aerially averaged data series, divided according to the physiogeographical divisions of Poland (Kondracki 2002). The black dashed line $\left(19^{\circ} \mathrm{E}\right)$ denotes the division on eastern and western subregions of Lakelands and Lowlands

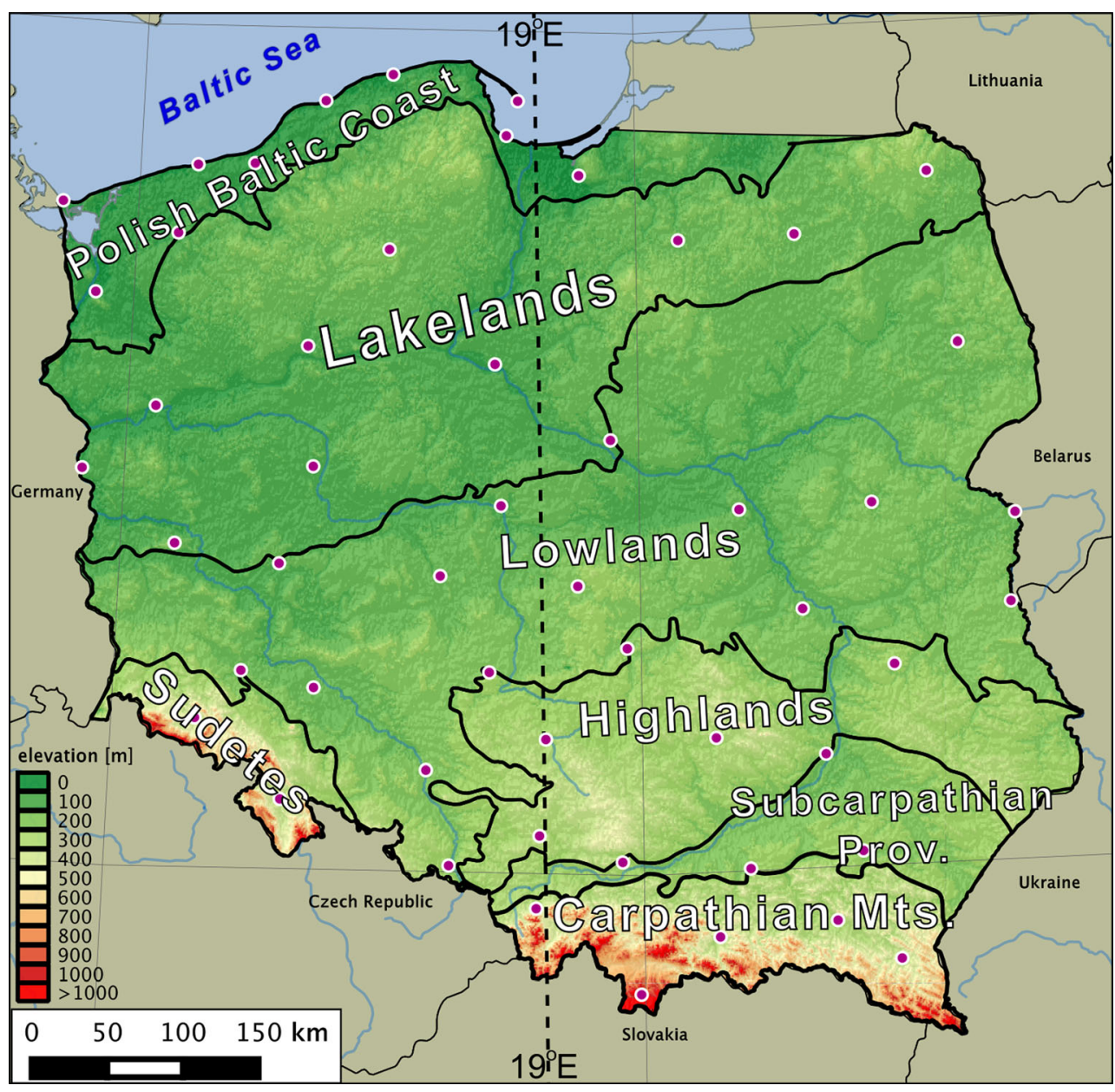

2010), using the distance weight factor defined by Alexandersson (1986).

$$
T_{\text {avg }}=\frac{\sum_{j=1}^{k} w_{j} T_{j}}{\sum_{j=1}^{k} w_{j}}
$$

where:

$T_{j}$ is the average temperature on station $j ; w_{j}$ is the weight factor for station $j ; k$ is the number of stations

$w_{j}=\exp \left(-d \cdot L_{j}\right)$

where:

$L_{j}$ is the distance from station $j$ to centroid of area; $d$ is the constant value (for temperature $0.001 \mathrm{~km}^{-1}$ ).

Those values obtained by Alexandersson's method are usually close (i.e. \pm 1 week) to mean regional values calculated with GIS-based regression Kriging interpolation method driven by longitude, latitude, altitude and distance to the Baltic Sea Coast (Fig. 2).
The trends for the duration and onset dates of the thermal seasons were examined via linear regression. The statistical significance of the trends was verified by the Mann-Kendall (MK) non-parametric test (Mann 1945, Kendall 1975) with a significance level of $1-\alpha=0.95$. This test has low sensitivity to abrupt breaks due to inhomogeneous time series and is highly recommended method by the World Meteorological Organization for the analysis of historical trends in climatological, hydrological and environmental time series.

\section{Characteristics of the thermal seasons}

The influence of continental and maritime air masses over Poland results in clearly seen transient character of thermal seasons' occurrence. Therefore, most of the analysed patterns show typical east-west gradients, which in some cases (only in areas below $500 \mathrm{amsl}$ ) may reach up to 50 days (Fig. 2). This shows huge complexity of thermal seasons' occurrence, even inside the same regions, and points out the most possible directions of anomalies (positive or negative) from the mean values described in the particular regions. 

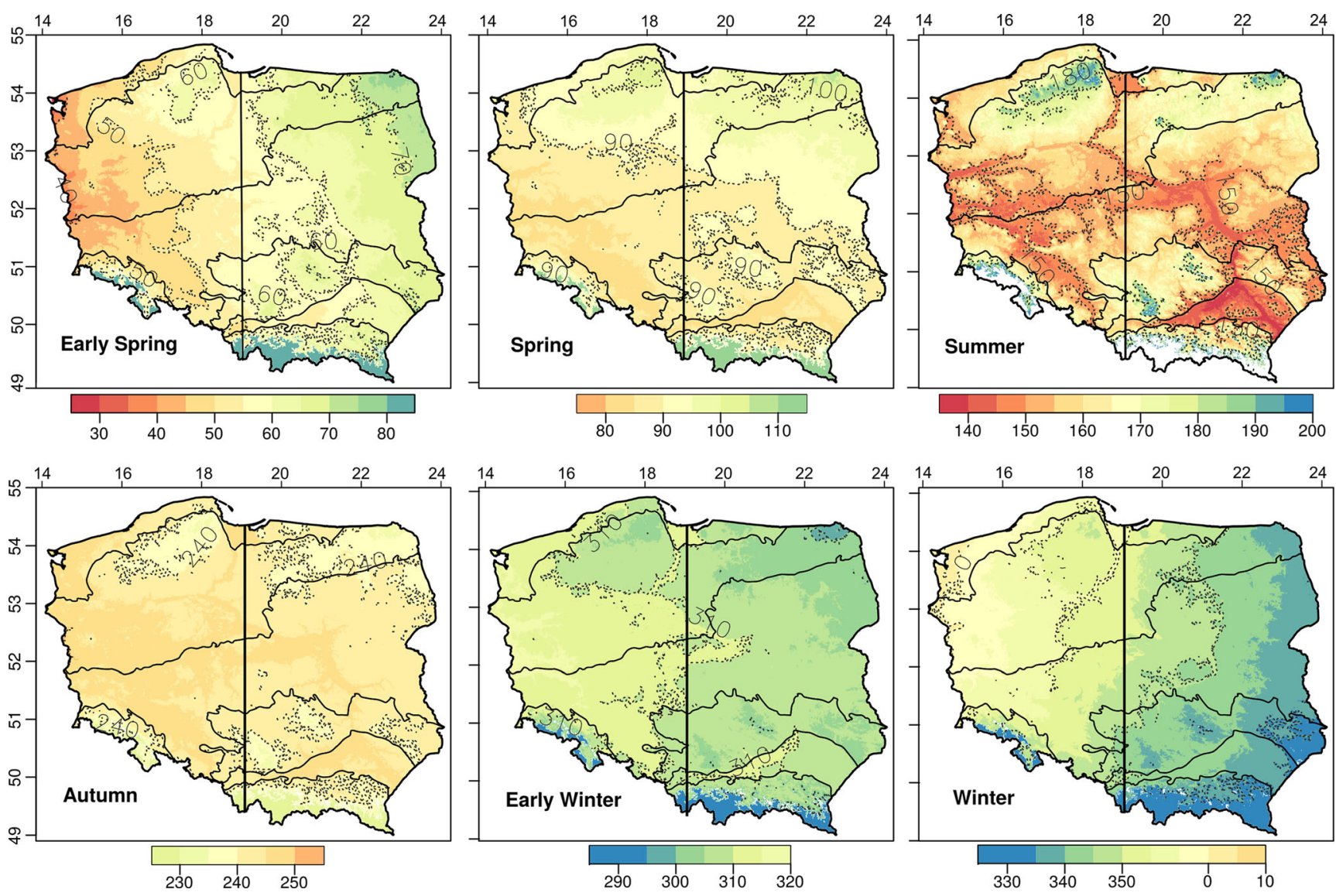

Fig. 2 Long-term spatial distribution of average beginning dates of the thermal seasons in the period 1951-2010. Values given in Julian days

\subsection{Average lengths and occurrence dates}

According to the monthly mean averages for the period from 1951 to 2010 , the thermal early spring starts in most regions of Poland in the second half of February or in the first days of March (Fig. 2, Table 2). This transient season is usually the shortest one, and its average length is a little more than a month (Table 3). The average thermal spring onset date is similar in the entire country, and it falls between the end of March and the beginning of April. Thermal spring is longer by 10 days on the coast and by 20 days in mountainous areas, in comparison to the Polish interior (62-64 days).

The earliest onset of thermal summer is observed in the Lowlands and in the Subcarpathian region (Fig. 2), where the season starts in the last days of May. In the mountainous areas and on the coast, the strong influence of local factors (elevation, impact of the Baltic Sea cooling) results in 2 weeks later start of thermal summer in comparison to neighbouring regions. Thermal summer lasts for about 3 months and is the longest thermal season in Poland (except the most southern areas, Table 3).

The onset of thermal autumn is usually observed between late August and early September. The average length of thermal autumn varies between 63 days in the Lowlands and the
Subcarpathian region to approximately 70 in the Sudetes and Carpathian regions (Table 3).

The thermal early winter starts typically in the first days of November. Thermal early winter, being a transient season, like thermal early spring, is relatively short, and it lasts only a few days longer than 1 month in most regions, with the exception of the Baltic Sea Coast, where it persists 50 days (Table 3).

The second longest thermal season, in most cases, is thermal winter, with an average duration of 75 days in Poland. However, due to the early onset of early spring and the late end of early winter, this season (thermal winter) is as short as 48 days on the coast. The beginning of the thermal winter does not vary significantly in most regions and it is observed between the 8th and 11th of December. Only on the Baltic Sea Coast winter starts later — on the 1st of January.

\subsection{Temporal variability and extremes characteristics of thermal seasons}

\subsubsection{Winter}

The relatively high mean temperature of winter months in the period from 1991 to 2010 in comparison to 1951 to 1970 (Fig. 3) can be especially well recognized in the late winter. 
Table 2 Average beginning dates of the thermal seasons in the period 1951-2010

\begin{tabular}{|c|c|c|c|c|c|c|}
\hline $\begin{array}{l}\text { Thermal season } \\
\text { Subprovince }\end{array}$ & Early spring & Spring & Summer & Autumn & Early winter & Winter \\
\hline Baltic Sea Coast & $18 \mathrm{Feb}$ & $3 \mathrm{Apr}$ & 13 Jun & 2 Sep & $10 \mathrm{Nov}$ & 1 Jan \\
\hline Eastern Lakelands & $8 \mathrm{Mar}$ & $5 \mathrm{Apr}$ & 6 Jun & 29 Aug & 31 Oct & $4 \mathrm{Dec}$ \\
\hline Western Lakelands & $22 \mathrm{Feb}$ & $30 \mathrm{Mar}$ & 2 Jun & $2 \mathrm{Sep}$ & $5 \mathrm{Nov}$ & $14 \mathrm{Dec}$ \\
\hline Lakelands & $28 \mathrm{Feb}$ & $1 \mathrm{Apr}$ & 3 Jun & 31 Aug & $3 \mathrm{Nov}$ & $10 \mathrm{Dec}$ \\
\hline Eastern Lowlands & 4 Mar & $1 \mathrm{Apr}$ & 31 May & 31 Aug & $1 \mathrm{Nov}$ & $5 \mathrm{Dec}$ \\
\hline Western Lowland & $19 \mathrm{Feb}$ & $26 \mathrm{Mar}$ & 30 May & $5 \mathrm{Sep}$ & $8 \mathrm{Nov}$ & $17 \mathrm{Dec}$ \\
\hline Lowlands & $25 \mathrm{Feb}$ & 29 Mar & 30 May & $3 \mathrm{Sep}$ & $5 \mathrm{Nov}$ & $11 \mathrm{Dec}$ \\
\hline Highlands & $27 \mathrm{Feb}$ & $30 \mathrm{Mar}$ & 2 Jun & 31 Aug & $3 \mathrm{Nov}$ & $8 \mathrm{Dec}$ \\
\hline Subcarpathian Prov. & $25 \mathrm{Feb}$ & $28 \mathrm{Mar}$ & 29 May & $3 \mathrm{Sep}$ & $5 \mathrm{Nov}$ & $9 \mathrm{Dec}$ \\
\hline Sudety Mts. & $25 \mathrm{Feb}$ & $2 \mathrm{Apr}$ & 14 Jun & $24 \mathrm{Aug}$ & $3 \mathrm{Nov}$ & $9 \mathrm{Dec}$ \\
\hline Carpathian Mts. & $1 \mathrm{Mar}$ & 2 Apr & 13 Jun & 25 Aug & $3 \mathrm{Nov}$ & $6 \mathrm{Dec}$ \\
\hline Eastern Poland & $2 \mathrm{Mar}$ & $1 \mathrm{Apr}$ & 3 Jun & 31 Aug & $2 \mathrm{Nov}$ & $6 \mathrm{Dec}$ \\
\hline Western Poland & $19 \mathrm{Feb}$ & $30 \mathrm{Mar}$ & 6 Jun & 2 Sep & $8 \mathrm{Nov}$ & $20 \mathrm{Dec}$ \\
\hline POLAND & $25 \mathrm{Feb}$ & $31 \mathrm{Mar}$ & 4 Jun & $1 \mathrm{Sep}$ & $5 \mathrm{Nov}$ & $12 \mathrm{Dec}$ \\
\hline
\end{tabular}

The temperature increase in February and March affects the duration of this thermal season, especially on the Baltic Sea Coast region, where 10 years without a thermal winter were recorded from 1988. Additionally, the onset date of thermal winter shifted from the second half of December to January. For the whole area of Poland, all six cases without thermal winter occurred between 1988 and 2008. In this period, even in mountainous areas, 2-3 years without any crossing of the threshold value $\left(0{ }^{\circ} \mathrm{C}\right)$ occurred. The longest thermal winter (122 days) was observed in the winter season 1995/1996, which ended on the 19th of March. In the Carpathian Mts., it was even 9 days longer, while on the Coast, it lasted for 108 days.

The variability of thermal winter is noticeable in the range of onset dates as well as durations of this season.
The earliest beginnings in most regions were noted in the first 10 days of November, while the latest dates were observed in the beginning of March. In less elevated regions, the beginning dates of the winter seasons most frequently occurred between the middle of November and last 10 days of December (from $81.5 \%$ in the Lakelands to $89.7 \%$ in the Carpathian Mts.). The exception to this rule is the Baltic Sea Coast, where every second onset of thermal winter was observed in December and every third onset was observed in January (Fig. 4).

There is a general tendency for the range of onset dates to increase in Poland. The observed range of the onset of winter season is now by $30 \%$ bigger than it was at the beginning of the second half of the twentieth century, and at the same time,
Table 3 Average durations (in days) of the thermal seasons in the period 1951-2010

\begin{tabular}{lcccccc}
\hline $\begin{array}{l}\text { Thermal season } \\
\text { Subprovince }\end{array}$ & Early spring & Spring & Summer & Autumn & Early winter & Winter \\
\hline Baltic Sea Coast & 44 & 71 & 81 & 69 & 52 & 48 \\
Eastern Lakelands & 28 & 62 & 84 & 63 & 34 & 94 \\
Western Lakelands & 36 & 64 & 92 & 64 & 39 & 70 \\
Lakelands & 32 & 63 & 89 & 64 & 37 & 80 \\
Eastern Lowlands & 28 & 60 & 92 & 62 & 34 & 89 \\
Western Lowland & 35 & 65 & 98 & 64 & 39 & 64 \\
Lowlands & 32 & 62 & 96 & 63 & 36 & 76 \\
Highlands & 31 & 64 & 90 & 64 & 35 & 81 \\
Subcarpathian Prov. & 31 & 62 & 97 & 63 & 34 & 78 \\
Sudety Mountains & 36 & 73 & 71 & 71 & 36 & 78 \\
Carpathian Mountains & 44 & 72 & 73 & 70 & 33 & 85 \\
Eastern Poland & 30 & 63 & 89 & 63 & 34 & 86 \\
Western Poland & 39 & 68 & 88 & 67 & 42 & 61 \\
POLAND & 34 & 65 & 89 & 65 & 37 & 75 \\
\hline
\end{tabular}


Fig. 3 Annual course and differences between the monthly mean air temperature in Poland in years 1991-2010 (in red) and 1951-1970 (blues) on the background of entire analysis period (1951-2010, black line). Values given in the figure above and below denote average monthly air temperature anomalies in years 1951-1970 (blue) and 1991-2010 (red) against the period of 1951-2010
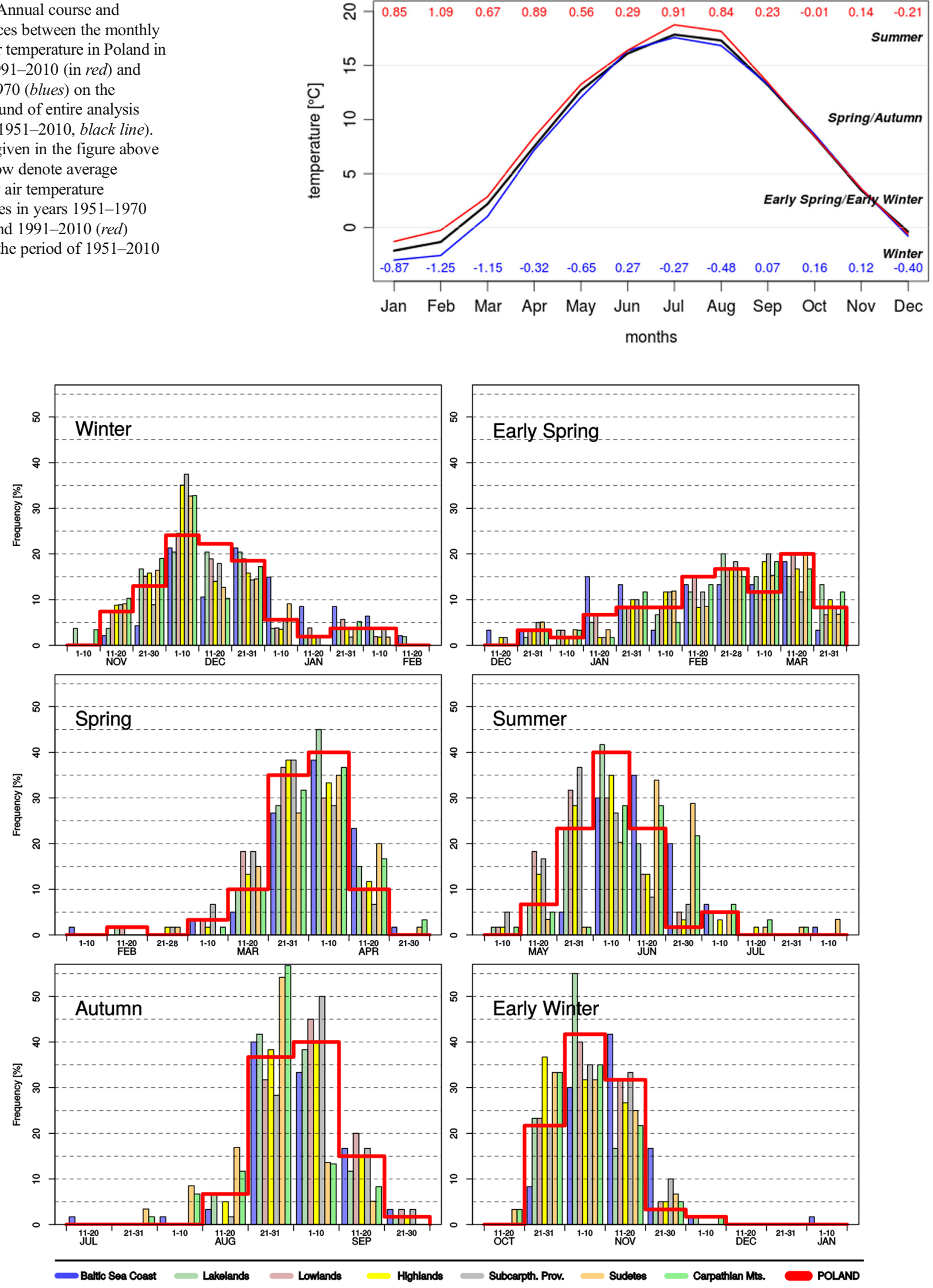

Fig. 4 Frequency of the thermal seasons' onset in the years 1951-2010 in the respective 10-day intervals of months 
the duration of the season changed remarkably in Poland especially in last 20 years also because of the lack of the occurrence of this season.

\subsubsection{Early spring}

As a consequence of the increasing number of years without a thermal winter, the beginning of early spring can occur as soon as the second half of December. Nevertheless, due to the large range of the onset and duration of thermal winter, the variation of the early spring occurrence and its length is relatively high (Fig. 4, Fig. 5). The onset dates of early spring's occurrence in Poland were noticed most frequently between the end of February and the middle of March (about half of all cases), while the latest incidents of the beginning of season took place by the end of March.

The transient character of early spring is seen when examining the duration of this season. The rapid increase of monthly mean temperature above $5{ }^{\circ} \mathrm{C}$ in the first half of the year (Fig. 3) may result in the shortening of thermal early spring, even to only a few days (e.g. 1952, 1962-64, 1987, 1996, 2006). However, the typical duration of early spring is between 20 and 50 days (about $75 \%$ of all cases, Fig. 4), while the longest recorded early spring lasted more than 100 days, which happened in years without a thermal winter. Taking into account the dispersion statistics for the early spring onset, it is worth noticing that the standard deviation computed in the years 1951-1970 amounted to 20 days in all regions, while
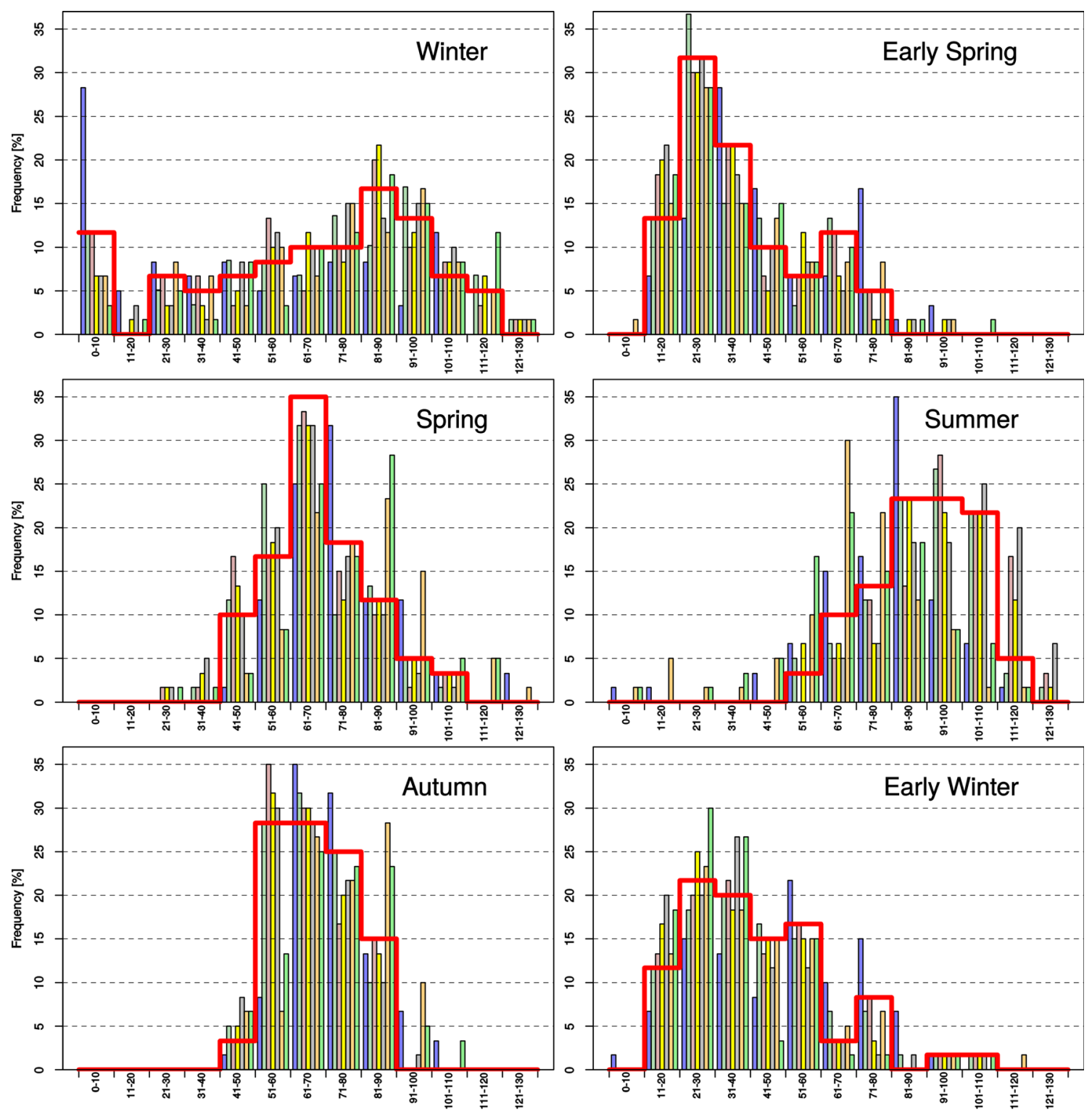

Baltic Sea Coast Lakelands $\rightleftharpoons$ Lowlands Highlands

Subcarpth. Prov. Sudetes

Carpathlan Mts. POLAND

Fig. 5 Frequency of the thermal seasons' duration in the years 1951-2010. Values given in days 
in the following periods, it was by $6-8$ days greater. Similarly, for the whole country, standard deviation values for thermal early spring's duration increased in every following 20 -year period from 12.9 to 19.9 days, which confirms the hypothesis of an increasing irregularity of this transient season.

\subsubsection{Spring}

The distribution of the onset dates of spring are similar in shape to a Gaussian distribution, with the highest probability of occurrence in late March and in the beginning of April (about $75 \%$ of all cases in Poland) (Fig. 4). From the middle of March until the middle of April, ca. $95 \%$ of thermal springs begin, although in all non-mountainous regions, there was one incident of the thermal spring onset in February (1990). On the other hand, the latest beginning of the season occurred in the middle of April (e.g. 1954$56,1958,1997)$, which results in a relatively small range of ending dates in comparison to earlier seasons. A histogram for the duration of thermal spring (Fig. 5) shows the dominance of the 61-70-day range for Poland, and $70 \%$ of all thermal springs lasted between 50 and 80 days. The shortest springs, lasting less than 30 days, were observed in the interior of the country. The longest ones exceeded 120 days locally (Baltic Sea Coast, Sudetes), while a maximum duration for entire Poland was 103-106 days (in the years 1974 and 1990, respectively). It is worth noting that there is no significant correlation between the duration of thermal spring and a lack of winter.

\subsubsection{Summer}

Thermal summer's onset may appear from the beginning of May to the beginning of August. The most typical dates occur between the end of May and the middle of June ( $86.7 \%$ of all cases in Poland), with a Gaussian distribution of onset dates (Fig. 4). Thermal summer, like thermal winter, is a season that may not appear during a year when the monthly mean temperature does not cross the threshold value. In the analysed period of time, such a situation was observed in only three regions (in 1965 on the Baltic Sea Coast and in 1978 on the Sudetes and the Carpathian Mts.), and after 1978, thermal summer always occurred in all analysed areas. Almost $70 \%$ of all thermal summers in Poland in the years 1951-2010 had durations of 81-110 days (Fig. 5), while the maximum for the whole country took place in 2002, when the season lasted for 119 days. Furthermore, thermal summer was the longest season in Poland in $60 \%$ of years in the period from 1951 to 2010 , but since the 1990s, summer was the longest season in $85 \%$ of the years (in the period from 1951 to 1970, it was longest in less than $50 \%$ ).

\subsubsection{Autumn}

Thermal autumn is the most stable among all the seasons. Above $90 \%$ of autumns' onset dates in all regions (excluding mountainous ones) occurred between the last days of August and the middle of September (Fig. 2). Single years with very early onset dates for thermal autumns were noted on the Baltic Sea Coast, in the Sudetes, and in the Carpathian Mts. (second part of July), while the latest beginnings of the season took place in the end of September in most regions (Fig. 4). Almost all autumns in Poland lasted between 51 and 90 days. The shortest one was observed in 1975 (41 days for whole territory of Poland), and the longest one lasted 104 days in the region of Carpathian Mts. It is worth noting that cases in which the limit of 100 days was trespassed upon took place only in the most northern and the most southern regions, mainly in years without summers or with only short summer seasons (e.g. 1965, 1978).

Autumn is the only season for which the standard deviation of the onset dates in most cases is lower than 910 days, which confirms the thesis regarding relatively small interannual variations (Rapp and Schoenwiese 1994; Piotrowicz 2010). Also, standard deviations for the duration of thermal autumn are the lowest among all seasons.

\subsubsection{Early winter}

The beginning of thermal early winter occurs most often between the last days of October and the middle of November (from $80 \%$ of all cases in the Baltic Sea Coast to $90-95 \%$ in other regions). The earliest incidents of the early winter onset were observed twice in the middle of October in mountainous regions $(1972,1976)$, while the latest one took place on the Baltic Sea Coast in 2006 when due to anomalously warm December 2006 the thermal early winter began on the 5th of January. Additionally, there were no cases of the early winter onset occurring later than the first 10 days of December. In fact, the early winter beginning dates are, together with thermal autumn's, the most stable ones ( $\sigma=8.4$ days in Poland), with an increasing tendency in the standard deviation of onset dates since the 1990s (Fig. 6). In some regions, the shortest seasons may last only several days ( 7 days in the Baltic Sea Coast in 2010), while the longest ones comprise of more than 100 days (e.g. an estimated 102 days in 1974 for the whole country). Usually, the duration of thermal early winter varies between 31 and 60 days $(73.3 \%$ in Poland, Fig. 5), with a standard deviation greater than 20 days. Among other seasons, these values are only higher for thermal winter. 
Fig. 6 Annual variation of the lengths and dates of the beginning of the thermal seasons in Poland, 1951-2010 (thin lines every 10 days, bolded denote months)

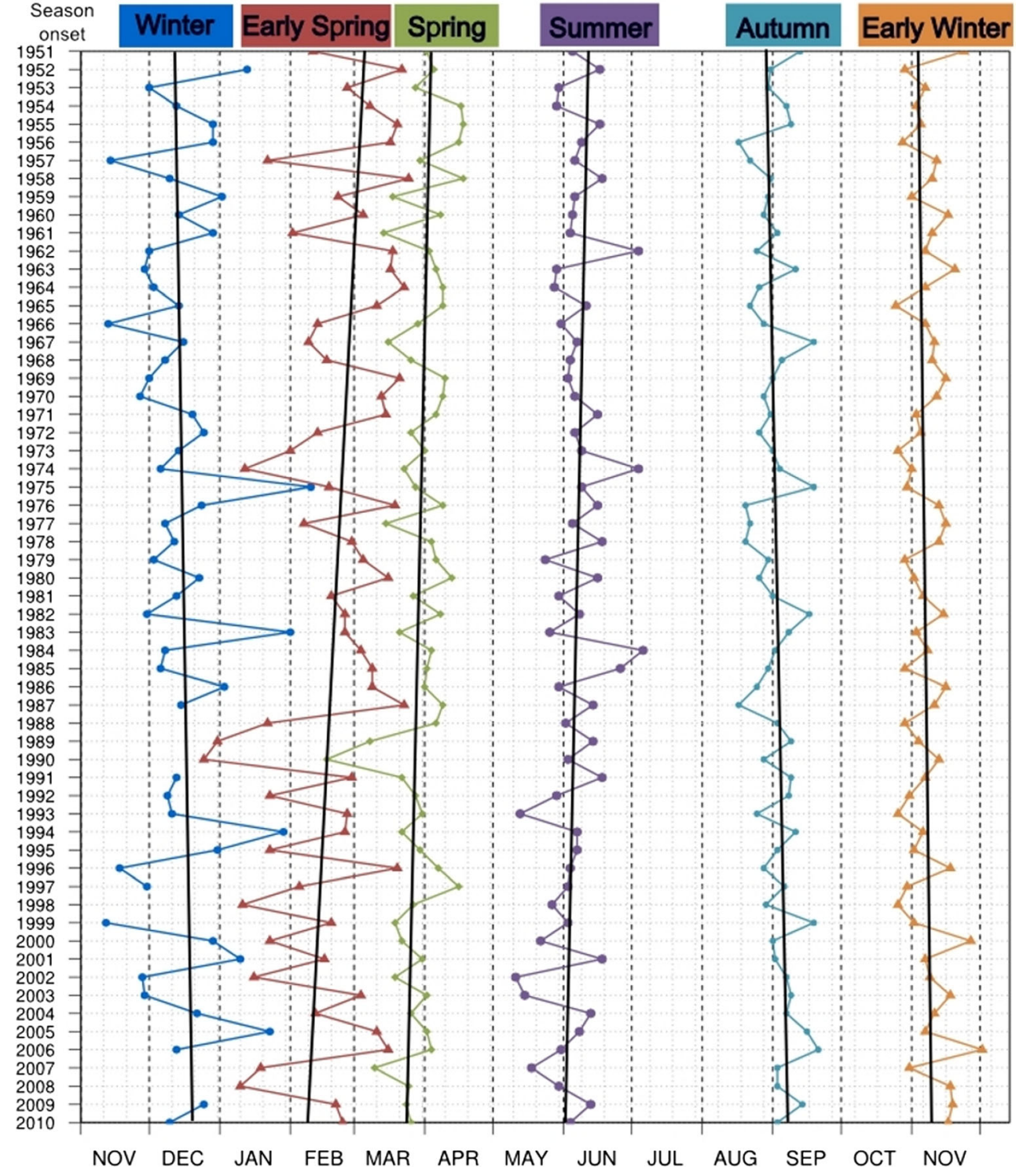

\section{Long-term trends of duration and onset dates of thermal seasons in the period 1951-2010}

Monthly mean air temperature changes (Fig. 3) influence long-term changes in the thermal seasons' characteristics; therefore, the linear regression coefficient of the thermal seasons' onset has a specific annual course. There is a negative tendency for the onset of seasons from early spring to summer, which means that they tend to begin earlier. The strongest trends are estimated for thermal early spring, with values from -0.55 to -0.40 day/year, and in all analysed regions, these values are significant according to the Mann-Kendall test (Table 4). For spring, the coefficients are almost twice smaller and vary from -0.28 up to -0.18 day/year, while slightly lower values occurred for thermal summer $(-0.20$ to -0.03$)$ and only 7 of 14 regions have significant trend coefficients.
In the following seasons, the tendency of their onset is positive in most cases, which means that thermal autumn, early winter and winter usually start later. Such results confirm the thesis presented by Menzel (2000), Ruosteenoja et al. (2010) and others for various parts of Europe. Autumn is the season with the highest tendency toward later onset, and it starts, on average, later by 0.14 days/year in Poland. The calculated trend coefficient values for the early winter season is slightly positive in the whole country and vary from 0.03 in the eastern part of Lakelands and Sudety Mts. to 0.10 days/ year on the Baltic Sea Coast. The area average of regression coefficient for the winter season in the whole country is about 0.09 days/year, but due to the relatively small rate of change, this result may vary from region to region. For example, on the Baltic Sea Coast, the season tends to start earlier ( -0.16 days/ year), while in the bordering region of the Lakelands, the 
Table 4 Linear regression coefficients of the thermal season onsets in years 1951-2010

\begin{tabular}{llllllr}
\hline $\begin{array}{l}\text { Thermal seasons } \\
\text { Subprovince }\end{array}$ & Early spring & Spring & Summer & Autumn & Early winter & Winter $^{\mathrm{a}}$ \\
\hline Baltic Sea Coast & -0.55 & -0.28 & -0.16 & 0.18 & 0.10 & -0.16 \\
Eastern Lakelands & -0.44 & -0.20 & -0.03 & 0.14 & 0.03 & 0.20 \\
Western Lakelands & -0.49 & -0.23 & -0.19 & 0.17 & 0.06 & 0.13 \\
Lakelands & -0.46 & -0.22 & -0.12 & 0.17 & 0.05 & 0.05 \\
Eastern Lowlands & -0.45 & -0.20 & -0.04 & 0.10 & 0.05 & 0.14 \\
Western Lowlands & -0.40 & -0.21 & -0.12 & 0.13 & 0.08 & 0.07 \\
Lowlands & -0.43 & -0.20 & -0.08 & 0.12 & 0.08 & 0.09 \\
Highlands & -0.46 & -0.18 & -0.09 & 0.12 & 0.05 & -0.01 \\
Subcarpathian Prov. & -0.46 & -0.21 & -0.19 & 0.09 & 0.06 & 0.00 \\
Sudety Mts. & -0.47 & -0.18 & -0.17 & 0.23 & 0.03 & -0.07 \\
Carpathian Mts. & -0.40 & -0.20 & -0.20 & 0.18 & 0.09 & -0.03 \\
Eastern Poland & -0.47 & -0.20 & -0.08 & 0.11 & 0.06 & 0.10 \\
Western Poland & -0.42 & -0.22 & -0.20 & 0.17 & 0.09 & 0.14 \\
POLAND & -0.46 & -0.21 & -0.16 & 0.14 & 0.07 & 0.12 \\
\hline
\end{tabular}

Values denote change in days per year (italicized if the trend coefficient is significant according to the MannKendall test at $1-\alpha=0.95$ )

${ }^{a}$ Years without presence of thermal winter was omitted in calculations tendency is the opposite ( 0.05 days/year), which confirms variation (regional sensitivity), even on a small scale, especially in cases where the magnitude of trend coefficient is close to zero.

Due to the multicourse trends of the occurrence of thermal seasons, the tendencies of their durations change as well (Table 5). The thermal winter onset is observed later nowadays, and in connection with winter shortening, the thermal early spring begins earlier by about 0.5 days/year in most regions. The rise of monthly mean temperature from
December to February (and only slightly smaller from March to May, Fig. 3) causes significant shortening of winter season (Fig. 6). The highest rate of change was computed for thermal winter in the western part of Lakelands region ( -7.5 days/decade), while the area average for Poland is equal to -6.4 days/decade, and only in the mountains is it less than -5 days/decade. The pace of observed changes increased rapidly in the last years of the twentieth century, which may suggest greater values for trends than were calculated for the whole period. If the presented trends (Table 4, Table 5) for
Table 5 Linear regression coefficients of the thermal season durations in years 1951-2010

\begin{tabular}{lllllll}
\hline $\begin{array}{l}\text { Thermal seasons } \\
\text { Subprovince }\end{array}$ & Early spring & Spring & Summer & Autumn & Early winter & Winter \\
\hline Baltic Sea Coast & 0.27 & 0.10 & 0.40 & -0.11 & -0.10 & -0.54 \\
Eastern Lakelands & 0.24 & 0.17 & 0.17 & -0.12 & 0.22 & -0.68 \\
Western Lakelands & 0.25 & 0.05 & 0.36 & -0.11 & 0.26 & -0.75 \\
Lakelands & 0.24 & 0.10 & 0.29 & -0.12 & 0.23 & -0.70 \\
Eastern Lowlands & 0.26 & 0.16 & 0.14 & -0.05 & 0.22 & -0.60 \\
Western Lowlands & 0.19 & 0.08 & 0.26 & -0.05 & 0.10 & -0.63 \\
Lowlands & 0.23 & 0.12 & 0.21 & -0.05 & 0.11 & -0.62 \\
Highlands & 0.29 & 0.09 & 0.21 & -0.07 & 0.00 & -0.53 \\
Subcarpathian Prov. & 0.25 & 0.01 & 0.28 & -0.02 & -0.01 & -0.53 \\
The Sudetes & 0.30 & 0.00 & 0.41 & -0.20 & -0.02 & -0.46 \\
Carpathian Mts. & 0.20 & -0.01 & 0.39 & -0.10 & -0.06 & -0.47 \\
Eastern Poland & 0.28 & 0.12 & 0.19 & -0.05 & 0.05 & -0.57 \\
Western Poland & 0.20 & 0.02 & 0.37 & -0.08 & 0.11 & -0.73 \\
POLAND & 0.25 & 0.05 & 0.30 & -0.07 & 0.11 & -0.64 \\
\hline
\end{tabular}

Values denote change in days per year (italicized if the trend coefficient is significant according to the MannKendall test at $1-\alpha=0.95$ ) 
thermal winter are extrapolated, this season in future may occur only occasionally in lower elevated country's regions. Nevertheless, the calculated duration of thermal season, e.g. in the Baltic Sea Coast for the period from 1981 to 2010, was already shorter than 10 days. This means that the lack of thermal winter in the most northern region may be a typical phenomenon relatively soon, although different GCM projections show that in anomalously cold years, thermal winter will still occur even at the end of twenty-first century.

Changes in the onset of thermal early spring are the greatest among the seasons (Table 4), and it tends to occur earlier by 0.46 days/year in Poland. Because of the fact that the onset of thermal spring is also observed earlier, the duration of early spring lengthens by $2-3$ days/decade (Table 5 ). The increase of the duration of thermal early spring is related with its replacing thermal winter, what means that this transient season (early spring) has become longer in recent years, as if its length is becoming comparable to that of thermal winter (Fig. 6). Additionally, taking into account the computed trends for the occurrence dates of early spring and early winter, those seasons may more often replace thermal winter, which raises further questions about the determining onset of early spring in such years.

The threshold temperature for the growing season and thermal spring is usually established as being the same value $\left(5^{\circ} \mathrm{C}\right)$, which, in fact, results in the possibility of using partially phenological and agrometeorological research as an indicator for season characteristics. Additionally, phenological changes are usually strongly correlated with monthly mean temperatures (Menzel et al. 2006). An analysis of phenological observations in Poland conducted by Tomaszewska and Rutkowski (1999) and Jabłońska et al. (2015) for 1951-1990 shows that the onset of vegetation in the spring season tend to occur earlier in the following 10 -year periods, while other phenological seasons seemed to be stable. According to Kożuchowski and Degirmendżić (2005), since the 1990s, onset dates have advanced, but due to the tendency toward earlier ending dates of the seasons, the length of the growing season did not change. In the context of European continent, similar research was conducted by Menzel (2000), who proved that the beginning of spring moved backward by about 6.3 days in the period 1959-1996. As calculated in this paper, thermal spring tends to occur ca. 0.21 days/year earlier, which is of slightly higher value in comparison to Menzel's calculations. Nevertheless, if the results are compared in analogous periods, they are almost equal (Europe, phenological spring -0.134 days/year; Poland, thermal spring -0.148 days/year). This confirms the suggestions made by some authors (Piotrowicz 2010) about using the thermal and phenological seasons' characteristics at the same time. Also, the slightly increasing duration of thermal spring ( 0.05 days/year in Poland) in most regions and the earlier occurrence of thermal summer $(-0.16$ days/year) remain in agreement with the tendencies recognized by Menzel et al. (2006). Additionally, the author proves the influence of monthly mean air temperature course (mean correlation with temperature equal to -0.53 ) on agricultural activities common for the summer season (tilling, harvesting, etc.), which may suggest the application of thermal seasons for agricultural purposes.

The duration of thermal summer is, next to the winter, a season with the strongest pace of change due to temperature increase. Calculated coefficient trends for the length of this season vary between 0.21 days/year in central parts of the country to ca. 0.4 days/year in the mountains and coastal zone. This means that in the near future, thermal summer will more often be the longest season, with a duration of above $1 / 3$ of the whole year.

Thermal autumn, according to calculations presented above, is the first season during a year that tends to occur later, by 1.4 days/decade on average (Table 4 ). Because of this, autumn is, together with thermal winter, the only season with a decreasing length according to the values presented in Table 5 (Poland -0.7 days/decade). According to Menzel (2000), in the period 1959 to 1996 , the growing season (threshold value the same as for the termination of autumn) became longer also due to the later cooling during autumn ( 4.5 days in 37 years). This is the same order of magnitude as in Poland during this same period (estimated rate of change $\sim 0.09$ day/year) for early winter onset.

\section{Discussion and conclusions}

Traditional division of Polish climate into four main thermal seasons (winter, spring, summer and autumn) with their duration of over 2 months, and two transient thermal seasons (early spring and early winter) with duration of a bit more than 1 month (Table 3 ) has changed remarkably in recent years. This is clearly due to a transformation of climate patterns observed in Central Europe (Heino et al. 1999; Kożuchowski and Żmudzka 2001; Degirmendžić et al. 2004; Kożuchowski and Degirmendžić 2005; BACC 2008; Brazdil et al. 2008).

Analysis presented in this study shows that all thermal seasons from early spring through spring and summer tend to start earlier, while autumn, early winter, and winter usually start later than they did in the second half of the twentieth century. Almost all other seasons are becoming longer due to rapid decreases in the duration of thermal winter (and partly thermal autumn).

The asymmetric warming observed during a year (Fig. 3) is especially well seen during the colder part of the year, which impacts rising lack of regularity of onset dates for thermal winter and thermal early spring since the middle of the 1980s (Fig. 6). Together with a rise in mean air temperature which occurred in winter months, the decrease of annual amplitude (Wibig and Głowicki 2002) caused the huge 
interannual variability of the thermal winter, which can be both: the longest one $(26.6 \%$ of all analysed cases in Poland), but also may not occur at all (10\% of cases in Poland, $22 \%$ in the Baltic Sea Coast region). Since the late 1980 s, the shortening of the season accelerated and years without thermal winter appeared more and more often (all six occurrences noticed in Poland), what is confirmed by the rising values of the standard deviation of its occurrence and its length, which is the highest among all thermal seasons.

The decrease in the number of days with thermal winter over the entire analysed period is estimated to be 6.4 days/ decade in Poland, which means the lack of that season's regular occurrence in most of the country in the following decades. This situation should be seen the fastest in the Baltic Sea Coast region, assuming that the calculated trends will not change significantly. In the authors', opinion the obtained regression coefficients for thermal winter cannot be interpreted literally, since the short- or mid-term very cold episodes, caused e.g. by "the European blocking" (Cattiaux et al. 2010; Anstey et al. 2013) may appear in future as well causing that the long-term mean duration of this season will remain slightly above 0 . Moreover, changes of the thermal winter durations are not linear even if the temperature increase would proceed at a constant rate. However, according to obtained results and taking into consideration most of future climate projections (e.g. ECHAM-5) years with relatively mild and long duration of thermal winter, as observed in years 1984 and 1999, are less probable in the future.

Due to the vanishing of thermal winter, the transient seasons of early spring and early winter are lengthening in most of the country. The earlier onset dates of early spring influence the increase of its duration, even though it is still the shortest season of the year, with a typical length below 40 days in most of regions of Poland. Thermal early winter is comparatively short, but the tendency of its lengthening is not so obvious according to results obtained for different regions (Table 5). Nevertheless, the results suggest equalization of both seasons neighbouring thermal winter and the loss of their transient character in a future. On the other hand, it must be noted that this equalization partially derives from methods of calculation the early winter and early spring duration in years where without thermal winter season, i.e. dividing the cold season equally to both neighbouring seasons.

The significant rise of mean temperature noted from March to May from 1951 to 2010 ( $1.41{ }^{\circ} \mathrm{C}$ in Poland) caused the shift of beginning dates for thermal spring toward the end of March. The thesis presented earlier (Rapp and Schoenwiese 1994; Kożuchowski and Degirmendžić 2005) concerning the changes in the thermal spring and autumn finds confirmation in the results shown. This is due to the significant diminishing of the temperature differences between these meteorological seasons (Fig. 3) which may be seen in the equal length (65 days, Table 3 ) of both seasons for the analysed period, with the tendency of thermal spring to increase in length (Table 5). Additionally, thermal autumn was the most stable season according to the standard deviation values for its duration and occurrence dates.

The longest thermal season in Poland is thermal summer, with the second highest linear coefficient values in terms of increasing length ( 0.3 days/year) among all other seasons. In recent years, it became undoubtly the longest thermal season, and since 1991, there were only three exceptions to this rule for the entire area of Poland (Fig. 6). Further increase of monthly mean air temperatures in summer months observed after year 2000 caused that duration of this season has already increased to 100 days, which may have further socioeconomic and environmental implications.

Open Access This article is distributed under the terms of the Creative Commons Attribution 4.0 International License (http:// creativecommons.org/licenses/by/4.0/), which permits unrestricted use, distribution, and reproduction in any medium, provided you give appropriate credit to the original author(s) and the source, provide a link to the Creative Commons license, and indicate if changes were made.

\section{References}

Alexandersson H (1986) A homogeneity test applied to precipitation data. Int J Climatol 6:661-675

Anstey JA, Davini P, Gray LJ, Woollings TJ, Butchart N, Cagnazzo C, Christiansen B, Hardiman SC, Osprey SM, Yang S (2013) Multimodel analysis of northern hemisphere winter blocking: model biases and the role of resolution. J Geophys Res 118:3956-3971

BACC Author Team (2008) Assessment of climate change for the Baltic sea basin. Springer-Verlag, Berlin

Biernacik D, Filipiak J, Miętus M, Wójcik R (2010) The variability of thermal conditions in Poland since 1951. The results of KLIMAT project. In: Bednorz E, Kolendowicz L (eds) Climate of Poland on the background of climate of Europe. Climate change and their consequences. Bogucki Publishing House, Poznan(in Polish)

Brazdil R, Chromá K, Dobrovolný P, Tolasz R (2008) Climate fluctuations in the Czech Republic during the period 1961-2005. Int J Climatol 29:223-242

Carter TR (1998) Changes in the thermal growing season in Nordic countries during the past century and prospects for the future. Agric Food Sci 7(2):161-179

Cattiaux J, Vautard R, Cassou C, Yiou P, Masson-Delmotte V, Codron F (2010) Winter 2010 in Europe: a cold extreme in a warming climate. Geophys Res Lett 37(20):L20704

Czernecki B, Miętus M (2010) Initial analyse of the thermal seasons occurrence and variability in chosen regions of Poland. Study Case of the Polish Baltic Coast and the Polish Highlands In: Bednorz E (ed) Climate of Poland on the Background of Climate of Europe Thermal and Pluvial Conditions 15:9-26

Degirmendžić J, Kożuchowski K, Żmudzka E (2004) Changes of air temperature and precipitation in Poland in the period 1951-2000 and their relationship to atmospheric circulation. Int J Climatol 24: 291-310

Heino R, Brazdil R, Forland E, Tuomenvirta H, Alexandersson H, Beniston M, Pfister C, Rebetez M, Rosenhagen G, Rösner S, Wibig J (1999) Progress in the study of climatic extremes in Northern and Central Europe. Clim Chang 42:151-181 
Intergovernmental Panel on Climate Change (2007) In Fourth assessment report of the intergovernmental panel on climate change. Solomon S, Qin D, Manning M, Chen Z, Marquis MC, Averyt KB, Tignor M, Miller HL (eds). Cambridge University Press

Irannezhad M, Kløve B (2015) Do atmospheric teleconnection patterns explain variations and trends in thermal growing season parameters in Finland? Int J Climatol. doi:10.1002/joc.4311

Jaagus J, Truu J, Ahas R, Aasa A (2003) Spatial and temporal variability of climatic seasons on the east European plain in relation to largescale atmospheric circulation. Clim Res 23:111-129

Jabłońska K, Kwiatkowska-Falińska A, Czernecki B, Walawender J (2015) Changes in spring and summer phenology in Poland-responses of selected plant species to air temperature variation. Pol J Ecol 63:291-299

Kendall MG (1975) Rank correlation methods. Griffin, London

Kondracki J (2002) Regional geography of Poland. PWN, Warsaw(in Polish)

Kożuchowski K, Degirmendžić (2005) Contemporary changes of climate in Poland: trends and variation in thermal and solar conditions related to plant vegetation. Pol J Ecol 53:283-297

Kożuchowski K, Żmudzka E (2001) Warming in Poland: scale and seasonal pattern of changes in the air temperature during the second half of 20th century. Przegl Geofizyczny 46:81-90(in Polish)

Kramer K, Leinonen I, Loistau D (2000) The importance of phenology for the evaluation of impact of climate change on growth of boreal, temperate and and mediterranean forests ecosystems: an overview. Int J Biometeorolog 44:67-75

Lobel BD, Field CB (2007) Global scale climate-crop yield relationships and the impacts of recent warming. Environ Res Lett 2:1-7

Mann HB (1945) Nonparametric tests against trend. Econometrica 13: 254-259

Menzel A, Fabian P (1999) Growing season extended in Europe. Nature 397:659

Menzel A (2000) Trends in phenological phases in Europe between 1951 and 1996. Int J Biometeorol 44:76-81

Menzel A (2003) Plant phenological anomalies in Germany and their relation to air temperature and NAO. Clim Chang 57:246-263

Menzel A, Sparks TH, Estrella N, Koch E, Aasa A, Aha R, Alm-Kuebler K, Bissoli P, Braslavska A, Briede A, Chmielewski FM, Crepinsek Z, Cunel Y, Dahl A, Defila C, Donnelly A, Filella Y, Jatczak K,
Mage F, Mestre A, Nordli O, Penuelas J, Pirinen P, Remisova V, Scheifinger H, Striz M, Susnik A, van Vliet AJH, Wielgolaski F-E, Zach S, Zust A (2006) European phenological response to climate change matches the warming pattern. Glob Chang Biol 12:19691976

Pielke RA, Garstang M, Lindsey C, Gusdorf J (1987) Use of a synoptic classification scheme to define seasons. Theor Appl Climatol 38:5768

Pielke Sr RA, Stohlgren T, Schell T, Parton W, Doesken N, Redmond K, Moeny J, Mckee T, TGF K (2002) Problems in evaluating regional and local trends in temperature: an example from eastern Colorado, USA. Int J Climatol 22:421-434

Piotrowicz K (2010) Seasonal and long-term weather type variability in Krakow. Jagiellonian University, Cracow(in Polish)

Rapp J, Schoenwiese CD (1994) Thermische Jahreszeiten als anschauliche charakteristik klimatischer Trends. Meteorol Z 3:9194

Rebetez M (1996) Public expectation as an element of human perception of climate change. Clim Chang 32:495-509

Romer E (1949) Farming periods in Poland. Prace Wrocławskiego Tow. Nauk., ser. B, 20 (in Polish)

Ruosteenoja K, Räisänen J, Pirinen P (2010) Projected changes in thermal seasons and the growing season in Finland. Int J Climatol 31:14731487

Song Y, Linderholm HW, Chen D, Walther A (2009) Trends of the thermal growing season in China, 1951-2007. Int J Climatol 30: 33-43

Tomaszewska T, Rutkowski Z (1999) Phenological seasons and their variability in years 1951-1990. Mat. Badawcze: Meteorologia 28, IMGW, Warsaw (in Polish)

Tveito OE, Forland EJ, Heino R, Hanssen-Bauer I, Alexandersson H, Dahlstroe B, Dreb A, Kern-Hansen C, Jonsson T, Vaarby-Laursen E, Westmann Y (2000) Nordic temperature maps. DNMI KLIMA No 9

Ustrnul Z, Czekierda D (2005) Application of GIS for the development of climatological air temperature maps: an example from Poland. Met. Apps 12:43-50. doi:10.1017/S1350482705001507

Wibig J, Głowicki B (2002) Trends of minimum and maximum temperature in Poland. Clim Res 20:123-133 